\title{
Socioepidemiological Determinants of Human
}

\section{Immunodeficiency Virus associated Tuberculosis Coinfection in Northern India: A 1:2 Matched Case Control Study}

\author{
Rakesh Khajuria $^{1}$, Sumeena Bajaj ${ }^{2}$, Jugal Kishore ${ }^{3}$, Divyansh Bajaj ${ }^{4}$
}

\begin{abstract}
Aims: Our study was designed to assess the sociodemographic correlates of human immunodeficiency virus infection-associated tuberculosis (HIV-TB) coinfection and elucidate its risk factors among patients attending a tertiary healthcare facility in Northern India.

Materials and methods: A 1:2 case-control study, wherein the case group (patients with HIV-TB) was compared with two control groups: I group comprising patients with active tuberculosis (TB) [but without human immunodeficiency virus (HIV)] and II group comprising HIV patients (who did not develop active TB during follow-up). Our questionnaire was designed to obtain data based on sociodemographic and detailed medical history.

Results: Significant differences were observed on comparing gender, age, educational level, per capita income, place of residence, and occupational profile between case group and control group I. Case group was more likely to reside in urban areas $(p=0.001)$ and had a lower average level of formal education $(p=0.009)$ as compared to control group II.

Conclusion: We found patients in the coinfected group to differ significantly from patients with active TB alone, but the trends were similar to the control group I. The most frequent high-risk behavior was observed to be unprotected sexual activity, which is in concordance with the national estimates by National AIDS Control Organization (NACO) and World Health Organization (WHO).

Clinical significance: To minimize the prevalence of HIV-TB, controlling HIV transmission and disease progression in people living with HIV-AIDS (PLHAs) is crucial. Moreover, if the life expectancy of PLHAs is to be improved, HIV should be diagnosed early in the natural history of infection. Keywords: Antiretroviral therapy, Human immunodeficiency virus, Human immunodeficiency virus infection-associated tuberculosis coinfection, people living with HIV-AIDS, Tuberculosis.

Journal of Medical Academics (2019): 10.5005/jp-journals-10070-0036
\end{abstract}

\section{INTRODUCTION}

Human immunodeficiency virus infection-associated tuberculosis (HIV-TB) poses an imperative and severe threat to healthcare system globally. ${ }^{1}$ Tuberculosis (TB) is one of the first opportunistic infections to appear in HIV-infected people and indeed, one of the key manifestations of HIV. The burden of HIV-TB poses unprecedented challenges on the public health systems, with India bearing the third highest burden in the world. ${ }^{2}$

Globally, 30\% of HIV-infected persons are estimated to have concomitant infection caused by Mycobacterium tuberculosis with prevalence rates varying from $14 \%$ in Europe to $46 \%$ in the Southeast Asian region. ${ }^{3}$ There are 2.1 million people living with HIV-AIDS (PLHAs) in India, with an estimated adult HIV prevalence of $0.27 \% .{ }^{4}$ Although only $5 \%$ of incident TB patients are HIV-infected, India bears about $10 \%$ of the global burden of HIV-TB. ${ }^{5}$ Tuberculosis, indeed, causes more than $25 \%$ mortality in PLHAs and hence is the leading preventable cause of death among the latter. ${ }^{6,7}$

The HIV-TB coinfection is further complicated by complex socioeconomic factors such as unemployment, poverty, malnutrition, overcrowding, and poor living conditions. ${ }^{8}$ Moreover, it has also been found to be intricately linked to male gender, smoking, alcoholism, and drug abuse. ${ }^{9,10}$ The prevalence of TB shows a bimodal distribution at the extremes of age. ${ }^{9}$ While active TB is more frequent in immune-compromised people, the odds of TB increases as the CD4 cell count decreases in PLHAs. ${ }^{9-11}$ The direct and indirect costs of illness due to HIV-TB have been observed to
${ }^{1}$ Department of Food Inspections, Integrated HQs of Ministry of Defence, Govt of India, Timarpur, New Delhi, India

${ }^{2}$ Ministry of Defence, Govt of India, Timarpur, New Delhi, India

${ }^{3}$ Department of Community Medicine, Vardhman Mahavir Medical College and Safdarjung Hospital (under Ministry of Health and Family Welfare), New Delhi, India

${ }^{4}$ Maulana Azad Medical College and Associated LN, Guru Nanak Eye Centre and Govind Ballabh Pant Hospitals, New Delhi, India

Corresponding Author: Sumeena Bajaj, Ministry of Defence, Govt of India, Timarpur, New Delhi, India, Phone: +91 9899962813, e-mail: sumeena.vasundhra@gmail.com

How to cite this article: Khajuria R, Bajaj S, Kishore J, et al. Socioepidemiological Determinants of Human Immunodeficiency Virus associated Tuberculosis Coinfection in Northern India: A 1:2 Matched Case Control Study. J Med Acad 2019;2(2):48-53.

Source of support: Nil

Conflict of interest: None

be more than $30 \%$ of the annual household income in developing countries and can have an appalling impact on the economy of the developing world. Thus, HIV-TB is not only a medical woe but a grave socioeconomic disaster, being aptly described as the "cursed duo."12,13

In a resource-limited setting like India, HIV seropositivity among TB patients varies from $9.4 \%$ in New Delhi to $30 \%$ in Mumbai. ${ }^{13,14}$ Moreover, the importance of concurrent treatment of HIV-TB cannot 
be undermined, since up to $50 \%$ of patients with HIV (without treatment) and concurrent TB would die prior to completion of antitubercular therapy (ATT). With the emergence of TB as a fatal complement in HIV-AIDS epidemiology, there is an urgent need to explore the probable multifactorial associations of HIV-TB coinfection. ${ }^{15}$

Our study attempts to do that by unfolding the underlying correlates of HIV-TB. It has been designed to assess the sociodemographic correlates of HIV-TB and elucidate its risk factors among patients attending a tertiary care health facility in Northern India.

\section{Materials and Methods}

\section{Study Design}

A follow-up 1:2 case-control study.

\section{Study Area}

The study was undertaken at the antiretroviral therapy (ART) clinic and TB [directly observed treatment short-course (DOTS)] center of large tertiary care health facility (Lok Nayak Hospital, LNH) located in the central district of New Delhi, India. The ART clinic has been functioning under the aegis of National AIDS Control Organization (NACO) and caters to a large population of Delhi and neighboring states. The study is a part of an ongoing project being undertaken at the ART clinic, LNH.

\section{Study Subjects (Inclusion and Exclusion Criteria)}

The study cases comprised HIV-TB coinfected patients who were registered in ART clinic and were on TB treatment (ATT) between October 01, 2016 and October 31, 2018. The controls comprised two control groups, i.e., control I (CGI) were TB patients without HIV who were registered in DOTS center of Lok Nayak hospital, New Delhi and had TB treatment card, while control II (CGII) were HIV patients without TB infection who were registered in ART clinic and did not develop active TB in the follow-up period. The CGI (TB only) was actively screened for HIV to rule out HIV and similarly, CGII (HIV only) was screened for TB to exclude it. Patients who were referred from other hospitals with incomplete baseline data or transferred out before complete evaluation were excluded from the study. Also patients who were severely ill, with psychiatric illness, under 15 years of age, on antimalignant drugs, or not willing to participate were excluded from the study. All patients were followed up till the end of the study.

\section{Sample Size}

The sample size was calculated using the Epi info ver.7 software (on the basis of results of similar study ${ }^{16}$ ), considering the expected exposure rate for controls as 0.81 , and a cumulative exposure rate of 0.62 with an odds ratio (OR) of 2.6 with $10 \%$ nonparticipation rate. Our calculation has been based on $90 \%$ statistical power with a significance level at 5\%. Per the calculated sample size, a total of 420 patients were divided equally into three groups: one case group and two control groups. Hence, the sample size was calculated to be 140 in each group.

\section{Sampling Methods}

Of the patients who met our inclusion and exclusion criteria, cases and controls were selected by systematic random sampling. We selected five patients on each study day (by simple random sampling) from the outpatient department list of the ART and TB centers. Case group (HIV-TB) and CGI patients were on ATT and were interviewed, whether in the intensive or in the continuation phase, during and after ATT completion. The CGII (HIV patients without TB) subjects were interviewed once during the study period. Both the control groups were representative of the population of the catchment area, from which HIV-TB coinfected cases had been detected.

\section{Matching}

Individual age and gender matching were done for both the cases and the control groups. The confounders such as smoking, alcoholism, hypertension, diabetes mellitus, chronic obstructive pulmonary disease, and malignancies were also matched the time of selection of control groups.

\section{Data Collection and Statistical Analysis}

A pretested, in-house questionnaire was designed to obtain data on sociodemographic and detailed medical profile (particularly pertaining to risk factors for HIV, TB, and HIV-TB coinfection) by direct interview. Sociodemographic variables included sex, age, residence, religion, marital status, educational status, occupation, and per capita monthly income (Gupta-Mahajan scale). The medical history comprised mode of detection and duration of HIV, CD4 count, risk factors, and family history of HIV-TB. The data were analyzed using Epi info ver.7 software. Univariate analysis was carried out for the association of clinical, laboratory, and sociodemographic variables. Crude ORs with $95 \%$ confidence intervals (Cls) were estimated. The level of significance was set at 0.05 .

\section{Ethical Considerations}

Ethical clearance was obtained from the Institutional Ethical Committee, Maulana Azad Medical College and associated LNH. All ethical requirements including voluntary, written informed consent, and confidentiality of subject' responses were strictly adhered to throughout the study.

\section{Results}

Our ART center had registered a total of 2,947 HIV cases during the study period (2016-2018), of which 1,857 were males, 901 were females, and 35 were transgenders and 154 were less than 15 years. While the total number of patients on ART was 1,456, the total number of HIV-TB patients were 950 (approximately a third of HIV cases).

As per Table 1, of the 420 patients studied, 267 (63.6\%) were males, 147 (35.0\%) females, and 6 (1.4\%) were transgenders. A greater proportion of male patients $(n=100,71.4 \%)$ were observed in the case group as compared to CGI $(n=74,52.9 \%)$ and CGII $(n=$ $93,66.4 \%)$. The mean age of the case group was $34.91 \pm 8.57$ years, with an age range of 20-65 years. Among the CGI, the mean age was observed to be $29.79 \pm 12.65$ years (range $=16-70$ years), while the mean age in CGll was found to be $35.21 \pm 8.71$ years (range $=20-65$ years). Both age and sex differences were found to be significantly different among case group vs CGI $(p=0.000)$.

As per Table 2, the case group subjects were more likely to be residents of urban areas as compared to CGI and CGII ( $p \leq 0.001)$ (the majority of whom were slum dwellers). A significant difference was observed in marital status on comparing cases with CGI $(p<0.001)$, with case group individuals being more likely to be married. Among the case group, a relatively higher proportion of individuals ( $n=$ $41,29.3 \%$ ) had attained primary education in comparison to CGI, while CGIl comprised maximum number of subjects with complete secondary education. More than $60 \%$ of the study subjects were Hindus; however, there was a significantly greater proportion of 
Table 1: Sex and age distribution of the study subjects

\begin{tabular}{|c|c|c|c|c|c|c|c|}
\hline Age and sex & & $\begin{array}{l}\text { Case group (HIV/ } \\
\text { TB) no (\%) }\end{array}$ & $\begin{array}{l}\text { Control group I } \\
\text { (TB) no (\%) }\end{array}$ & $\begin{array}{l}\text { Control group II } \\
\text { (HIV) no (\%) }\end{array}$ & Total no. (\%) & $\begin{array}{l}\text { p value case vs } \\
\text { control I }\end{array}$ & $\begin{array}{l}p \text { value case vs } \\
\text { control II }\end{array}$ \\
\hline \multirow[t]{3}{*}{ Sex } & Males & $100(71.4)$ & $74(52.9)$ & $93(66.4)$ & $267(63.6)$ & 0.001 & 0.58 \\
\hline & Females & 39 (27.9) & $66(47.1)$ & $42(30.0)$ & $147(35.0)$ & & \\
\hline & Transgender & $1(0.7)$ & $0(0.0)$ & $5(3.6)$ & $6(1.4)$ & & \\
\hline \multirow[t]{5}{*}{ Age (years) } & $15-24$ & $9(6.4)$ & $62(44.3)$ & $11(7.9)$ & $82(19.5)$ & 0.000 & 0.78 \\
\hline & $25-34$ & $57(40.7)$ & $34(24.3)$ & $58(41.4)$ & $149(35.5)$ & & \\
\hline & $35-44$ & $59(42.1)$ & $24(17.1)$ & $52(37.1)$ & $135(32.1)$ & & \\
\hline & $45-54$ & $11(7.9)$ & $12(8.6)$ & 16 (11.4) & $39(9.3)$ & & \\
\hline & $\geq 55$ & $4(2.9)$ & $8(5.7)$ & $3(2.1)$ & $15(3.6)$ & & \\
\hline
\end{tabular}

Table 2: Sociodemographic profile of the study subjects

\begin{tabular}{|c|c|c|c|c|c|c|c|}
\hline \multicolumn{2}{|c|}{ Sociodemographic variables } & \multirow{2}{*}{$\begin{array}{l}\text { Case group (HIV/ } \\
\text { TB) no (\%) } \\
75(53.6)\end{array}$} & \multirow{2}{*}{$\begin{array}{l}\text { Control group I } \\
\text { (TB) no (\%) } \\
58(41.4)\end{array}$} & \multirow{2}{*}{$\begin{array}{l}\begin{array}{l}\text { Control group /I } \\
\text { (HIV) no (\%) }\end{array} \\
51(36.4)\end{array}$} & \multirow{2}{*}{$\begin{array}{l}\text { Total no. (\%) } \\
184(43.8)\end{array}$} & \multirow{2}{*}{$\begin{array}{l}p \text { value case vs } \\
\text { controll } \\
0.000\end{array}$} & \multirow{2}{*}{$\begin{array}{l}\text { p value case vs } \\
\text { control II } \\
0.001\end{array}$} \\
\hline Residence & Urban & & & & & & \\
\hline & Rural & $27(19.3)$ & $0(0.0)$ & $50(35.7)$ & $77(18.3)$ & & \\
\hline & Slum & $34(24.3)$ & $82(58.6)$ & $37(26.4)$ & $153(36.4)$ & & \\
\hline & Homeless & $4(2.9)$ & $0(0.0)$ & $2(1.4)$ & $6(1.4)$ & & \\
\hline \multirow[t]{3}{*}{ Marital status } & Married & $98(70.0)$ & $85(60.7)$ & $94(67.1)$ & $277(66.0)$ & 0.000 & 0.50 \\
\hline & Single & $23(16.4)$ & $51(36.4)$ & $20(14.3)$ & $94(22.4)$ & & \\
\hline & $\begin{array}{l}\text { Divorced and } \\
\text { widow }\end{array}$ & $19(13.6)$ & $4(2.8)$ & $26(18.6)$ & 49 (11.6) & & \\
\hline \multirow{5}{*}{$\begin{array}{l}\text { Educational } \\
\text { status }\end{array}$} & Illiterate & $40(28.6)$ & $53(37,9)$ & 39 (27.9) & $132(31.4)$ & 0.011 & 0.009 \\
\hline & Primary & $41(29.3)$ & $27(19.3)$ & $37(26.4)$ & $105(25.0)$ & & \\
\hline & Secondary & $33(23.6)$ & $35(25.0)$ & $47(33.6)$ & $115(27.1)$ & & \\
\hline & $\begin{array}{l}\text { Higher second- } \\
\text { ary }\end{array}$ & $25(17.9)$ & $16(11.4)$ & $10(7.1)$ & $51(12.1)$ & & \\
\hline & $\begin{array}{l}\text { Graduate and } \\
\text { above }\end{array}$ & $1(0.7)$ & $9(6.4)$ & $7(5.0)$ & $17(4.0)$ & & \\
\hline \multirow[t]{5}{*}{ Religion } & Hindu & $102(72.9)$ & 75 (53.6) & $110(78.6)$ & $287(68.3)$ & 0.000 & 0.51 \\
\hline & Muslim & $29(20.7)$ & $63(45.0)$ & $22(15.7)$ & $114(27.1)$ & & \\
\hline & Sikh & $7(5.0)$ & $0(0.0)$ & $5(3.6)$ & $11(2.6)$ & & \\
\hline & Christian & $1(0.7)$ & $2(1.4)$ & $2(1.4)$ & $5(1.2)$ & & \\
\hline & Others & $1(0.7)$ & $0(0.0)$ & $1(0.7)$ & $2(0.5)$ & & \\
\hline
\end{tabular}

Table 3: Distribution of per capita income of the study subject

\begin{tabular}{|c|c|c|c|c|c|c|c|}
\hline Economic profile & & $\begin{array}{l}\text { Case group (HIV/ } \\
\text { TB) no (\%) }\end{array}$ & $\begin{array}{l}\text { Control group I } \\
\text { (TB) no (\%) }\end{array}$ & $\begin{array}{l}\text { Control group II } \\
\text { (HIV) no (\%) }\end{array}$ & Total no. (\%) & $\begin{array}{l}\text { p value case vs } \\
\text { controll }\end{array}$ & $\begin{array}{l}p \text { value case vs } \\
\text { control II }\end{array}$ \\
\hline \multirow{5}{*}{$\begin{array}{l}\text { Per capita } \\
\text { income (Rs.)* }\end{array}$} & Lower $<500$ & $14(10.0)$ & 33 (23.6) & $22(15.7)$ & 69 (16.4) & & \\
\hline & $\begin{array}{l}\text { Upper lower } \\
500-1,299\end{array}$ & $74(52.9)$ & $70(50.0)$ & $73(52.1)$ & $217(51.7)$ & & \\
\hline & $\begin{array}{l}\text { Lower middle } \\
1,300-2,499\end{array}$ & $32(22.9)$ & $22(15.7)$ & $26(18.6)$ & $80(19.0)$ & 0.035 & 0.219 \\
\hline & $\begin{array}{l}\text { Upper middle } \\
2,500-3,999\end{array}$ & $9(6.4)$ & $7(5.0)$ & $14(10.0)$ & $30(7.1)$ & & \\
\hline & Upper 4,000 & $11(7.9)$ & $8(5.7)$ & $5(3.6)$ & $24(5.7)$ & & \\
\hline
\end{tabular}

*Monthly per capita income was calculated as per Gupta-Mahajan scale

self-reported Muslims $(p<0.001)$ in CGI. Majority of the subjects in all the three groups were housewives (22.6\%) followed by businessmen (16.4\%) and skilled workers (15.2\%).
As per Table 3, the vast majority of our subjects belonged to the upper lower socioeconomic class (case group $=74,52.9 \%$ and $\mathrm{CGI}=70,50.0 \%$ and CGII $=73,52.1 \%)$. The CGI had a significantly 
Table 4: Mode or detection of human immunodeficiency virus status among study subjects

\begin{tabular}{|c|c|c|c|c|}
\hline Mode of detection & $\begin{array}{l}\text { Case group I } \\
\text { (HIV/TB) no. (\%) }\end{array}$ & $\begin{array}{l}\text { Control group II } \\
\text { (HIV) no. (\%) }\end{array}$ & $\begin{array}{l}\text { p value case vs } \\
\text { control II }\end{array}$ & Total no. (\%) \\
\hline During prolonged illness & $60(42.9)$ & $72(51.4)$ & 0.15 & $132(47.1)$ \\
\hline During detection of TB infection & $54(38.6)$ & $18(12.9)$ & 0.000 & $72(25.7)$ \\
\hline Voluntary testing & $25(17.9)$ & $39(27.9)$ & 0.09 & $64(22.9)$ \\
\hline During antenatal checking & $1(0.7)$ & $5(3.6)$ & $0.10^{*}$ & $6(2.1)$ \\
\hline While donating blood & $0(0.0)$ & $4(2.9)$ & $0.06^{*}$ & $4(1.4)$ \\
\hline While seeking employment abroad & $0(0.0)$ & $2(1.4)$ & $0.24^{*}$ & $2(0.7)$ \\
\hline Total & $140(100.0)$ & $140(100.0)$ & - & $280(100.0)$ \\
\hline
\end{tabular}

*Fisher exact test

Table 5: Univariate analysis of risk factors among case group and control groups (I and II)

\begin{tabular}{|c|c|c|c|c|c|c|c|c|}
\hline \multicolumn{2}{|c|}{ Possible risk factors } & \multirow{2}{*}{$\begin{array}{l}\text { Case group } \\
\text { (HIV/TB) }\end{array}$} & \multirow{2}{*}{$\begin{array}{l}\text { Control } \\
\text { group I (TB) } \\
74\end{array}$} & \multirow{2}{*}{$\frac{O R(95 \% C l)}{2.29(1.35-3.9)}$} & \multirow{2}{*}{$\frac{p \text { value }}{0.001}$} & \multirow{2}{*}{$\begin{array}{l}\text { Control } \\
\text { group II (HIV) } \\
93\end{array}$} & \multirow{2}{*}{$\frac{O R(95 \% C l)}{1.16(0.67-2.01)}$} & \multirow{2}{*}{$\begin{array}{l}p \text { value } \\
0.57\end{array}$} \\
\hline Sex & Male & & & & & & & \\
\hline & Female & 39 & 66 & & & 24 & & \\
\hline \multirow[t]{2}{*}{ Age (years) } & $<35$ & 66 & 96 & $0.43(0.26-0.71)$ & 0.000 & 69 & $1.09(0.66-1.79)$ & 0.70 \\
\hline & $\geq 35$ & 74 & 46 & & & 71 & & \\
\hline \multirow[t]{2}{*}{ Education } & $\leq$ Primary & 81 & 80 & $1.03(0.62-1.70)$ & 0.90 & 76 & $1.16(0.70-1.91)$ & 0.54 \\
\hline & Others & 59 & 60 & & & 64 & & \\
\hline \multirow[t]{2}{*}{ Residence } & Urban & 75 & 58 & $1.63(0.99-2.69)$ & 0.041 & 51 & $2.01(1.21-3.34)$ & 0.003 \\
\hline & Others & 65 & 82 & & & 89 & & \\
\hline \multirow{2}{*}{$\begin{array}{l}\text { Per capita } \\
\text { income (Rs) }\end{array}$} & $<500$ & 14 & 33 & $0.36(0.17-0.74)$ & 0.002 & 22 & $0.60(0.27-1.28)$ & 0.15 \\
\hline & $>500$ & 126 & 107 & & & 118 & & \\
\hline \multirow{2}{*}{$\begin{array}{l}\text { History of TB in } \\
\text { family }\end{array}$} & Yes & 32 & 20 & $1.64(0.85-3.17)$ & 0.11 & 19 & $1.74(0.90-3.40)$ & 0.08 \\
\hline & No & 117 & 120 & & & 121 & & \\
\hline \multirow{2}{*}{$\begin{array}{l}\text { Currently } \\
\text { smoking status }\end{array}$} & Yes & 92 & 69 & $1.97(1.19-3.29)$ & 0.005 & 67 & $2.09(1.25-3.48)$ & 0.003 \\
\hline & No & 48 & 71 & & & 73 & & \\
\hline \multirow{2}{*}{$\begin{array}{l}\text { Duration of HIV } \\
\text { infection }\end{array}$} & $\leq 3$ years & 108 & * & 73 & $3.10(1.85-5.19)$ & 0.000 & & \\
\hline & $>3$ years & 32 & & 67 & & & & \\
\hline
\end{tabular}

*Not applicable

lower per capita income compared to the case group patients $(p=0.035)$.

As per Table 4, HIV testing during the course of prolonged illness was the commonest mode of HIV detection among our study subjects. An appreciable number of case group subjects $(p<0.001)$ were diagnosed with HIV during TB testing, whereas a larger number of CGII were diagnosed either during voluntary testing ( $p=0.09$ ) or during blood donation $(p=0.06)$. More than $75 \%$ of the case group was known to be retrovirus positive for last 3 years, while it was vice versa for CGII.

More than $90 \%$ of the subjects in the case group reported to have unprotected sexual intercourse followed by CGII (87.9\%). An almost equal proportion of subjects mentioned blood transfusion, injury with contaminated materials, and drug abuse as their exposures, with a significant difference $(p<0.05)$ being observed between case group (HIV-TB) and CGII when compared to CGI. The CD4 count of less than 200 was observed in $35.0 \%$ subjects belonging to the case group as compared to CGII (27.9\%).
This difference in CD4 count was statistically nonsignificant $(p=0.19)$.

Table 5, on univariate analysis, the factors found to be associated with HIV-TB coinfection, between case group and CGI were gender (males, $\mathrm{OR}=2.29,95 \% \mathrm{Cl}: 1.35-3.9)$, age $(<35$ years, $\mathrm{OR}=0.43,95 \%$ $\mathrm{Cl}: 0.26-0.71)$, urban residence $(\mathrm{OR}=1.63,95 \% \mathrm{Cl}: 0.99-2.69)$, and current smoking status ( $\mathrm{OR}=1.97,95 \% \mathrm{Cl}: 1.19-3.29)$. The factors found to be positively associated with HIV-TB, between case group and CGII, were urban residence $(\mathrm{OR}=2.01,95 \% \mathrm{Cl}$ : 1.21-3.34), current smoking status $(\mathrm{OR}=2.09,95 \% \mathrm{Cl}: 1.25-3.48)$, and duration of HIV infection ( $<3$ years, OR $=3.10,95 \% \mathrm{Cl}$ : 1.85-5.19). It was also observed that among the case group and CGI, the difference was highly significant for age ( $>35$ years) and male gender $(p=0.001)$.

\section{Discussion}

Our present study seeks to examine the sociodemographic variants and the risk factors for the HIV-TB coinfection. 
In a study conducted by Rajasekaran et al., $74.5 \%$ of 4,383 HIV-TB patients were males and a statistically significant difference $(p<$ 0.001) of the prevalence of coinfection was observed between the genders. ${ }^{17}$ Per NACO estimates, HIV prevalence rate for adult females is $0.29 \%$, while for males it is $0.43 \% .{ }^{4}$ We found that a significantly greater proportion of male patients suffered from coinfection compared to TB alone. However, no difference in sex distribution was found on comparing coinfected patients with HIV-positive individuals. This seems to suggest that the differential sex-wise distribution arises primarily from the greater predilection of males to risk factors for HIV.

National AIDS Control Organization estimates suggest that prevalence of HIV is higher in the age group of $15-49$ years ( $88.7 \%$ ), indicating that HIV-AIDS still affects the economically productive members of the society. ${ }^{18}$ Most of our case group patients were in the age group of 25-44 years, a distribution not much different from CGIl but deviated significantly from the age distribution of CGI. This again suggests that it is the population distribution of HIV infection that primarily drives the risk of coinfection. ${ }^{18-20}$

In keeping with the population norms of our study setting, the vast majority of subjects were Hindus followed in frequency by Muslims. Most of the study subjects were married at the time of interview. When questioned about literacy levels, a significantly greater proportion of patients infected with HIV alone had higher literacy level and patients with active TB alone had lower literacy levels, when compared to the coinfected patients. This is, in turn, concordant with a study by Carvalho et al. which found that subjects with a lower educational level had a higher risk of developing $\mathrm{TB}^{16}{ }^{16}$ In accordance with the trends for active TB, as reported in multiple previous studies, we observed that patients with active TB alone had a significantly lower per capita income as compared to patients with coinfection and patients with HIV infection alone. ${ }^{16,18,19}$ This reiterates the fact that HIV infection predisposes to coinfection, irrespective of the demographic profile of active TB. As regards the habitat, majority of CGI resided in urban slums, a finding backed by reports of epidemiological trends for TB. ${ }^{7,15}$ When, however, patients acquire a predisposition for TB disease by means of HIV infection, their distribution becomes more uniform among urban areas, rural areas, and slums, mimicking the prevalence rates of HIV infection.

A majority of our coinfected patients had been known to be infected with HIV for a period of less than 3 years at the time of interview. This finding is likely confounded by the fact that a great proportion of these patients were diagnosed to have HIV infection in the course of routine investigation for active TB disease. Patients in the coinfected group had lower average CD4 counts when compared to their counterparts with HIV infection alone, the finding that authenticates the known natural history of HIV infection. $^{18,21-23}$

Our study, indirectly, reflects the success of NACP efforts as evidenced by a higher rate of HIV detection through voluntary testing. However, it reiterates the need for increasing awareness and encouraging voluntary testing, particularly among groups with high-risk social behaviors. ${ }^{24}$

When questioned regarding risk factors for acquiring HIV infection, both coinfected and CGII had similar variants but were found to differ significantly from CGI. The most frequent highrisk behavior by far was unprotected sexual activity, which is in concordance with the national estimates by NACO and World Health Organization (WHO). ${ }^{4,6,7}$

\section{Conclusion}

Our study was designed to determine the unique sociodemographic characteristics that distinguish HIV-TB coinfected patients from patients infected with either disease alone.

Our study is the first study conducted in the capital city of India, i.e., Delhi, which highlights the important socioepidemiological determinants of HIV-TB coinfection, in large population of Delhi. With regard to the sociodemographic variables of age, sex, literacy levels, per capita income, and habitation, we found patients in the coinfected group differ significantly from patients with active TB alone but had shown similar trends to that of the patients with only HIV infection. In a region with higher TB endemicity, this seems to suggest that the native distribution of HIV is a stronger driver for coinfection. While TB prevention and treatment is the key to reduce its prevalence in the population, controlling HIV transmission and minimizing the rates of disease progression for PLHAs are indeed the crucial facets.

Both HIV-AIDS and TB are socially driven diseases, and, hence, understanding the social characteristics of each disease individually and of their coexistence is vital to achieving infection control.

\section{Clinical significance}

Majority of our patients were tested for HIV status either during the course of a prolonged illness or during evaluations for active TB disease. At the time of interview, most of the patients with HIV and active TB disease had held the diagnosis for less than 3 years. These were all patients in AIDS clinical stage 3, a diagnosis that would warrant immediate initiation of ART. If the life expectancy and quality of PLHAs is to be improved, it is essential that HIV testing should occur earlier in the natural history of infection. This presents a challenge to NACP by highlighting the necessity to enhance voluntary testing, particularly in the high-risk groups.

\section{References}

1. Kendrad N, Carolyn W, Neil G. Infectious diseases epidemiology, theory and practice. Aspen publishers; 2001. pp. 411, 428, 521.

2. WHO. Global Tuberculosis Report 2016. Geneva: World Health Organization. (homepage on internet).c2014.(updated 31 Mar 2016, cited 30 Nov 2016). Available at www.who.int/tb/publications/ global_report/gtbr14_executive_summary.pdf (last Assessed on 25 June 2016).

3. Corbett EL, Watt CJ, Walker N. The growing burden of tuberculosis: Global trends and interactions with the HIV epidemic. Arch Intern Med 2003;163(9):1009-1021. DOI: 10.1001/archinte.163.9.1009.

4. Narrative country progress report of India: Global AIDS Response Progress Reporting 2015. NACO.GOI/NACO/SIM/GR-RPT/200415. Available from: http://www.unaids.org/sites/default/files/country/ documents/IND_narrative_report_2015.pdf, (last assessed on 25 June 2016).

5. Agarwal U, Kumar A, Behera D. Profile of HIV associated tuberculosis at a tertiary institute in setting of free anti-retroviral therapy. JAPI 2009;57:685.

6. Sculier D, Getahun H, Granich R, et al. Priority research questions for TB/HIV in HIV-prevalent and resource-limited settings. Geneva: World Health Organization; 2010.

7. World Health Organization. Guidelines for intensified tuberculosis casefinding and isoniazid preventive therapy for people living with HIV in resource constrained settings; 2011 [cited 2014 Nov 13]. Available from: http://whqlibdoc.who.int/publications/2011/9789241500708_ eng.pdf.

8. Vikram A. HIV and tuberculosis: a "cursed duo" in the HAART era. J Assoc Physicians India 2009;57:681-682. 
9. Getahun H, Gunneberg C, Granich R, et al. HIV infection-associated tuberculosis: the epidemiology and the response. Clin Infect Dis 2010;50(Suppl 3):S201-S207. DOI: 10.1086/651492.

10. Fenner L, Forster M, Boulle A, et al. Tuberculosis in HIV programmes in lower-income countries: practices and risk factors. Int J Tuberc Lung Dis 2011;15(5):620-627. DOI: 10.5588/ijtld.10.0249.

11. Hwang JH, Choe PG, Kim NH, et al. Incidence and risk factors of tuberculosis in patients with human immunodeficiency virus infection. J Korean Med Sci 2013;28(3):374-377. DOI: 10.3346/ jkms.2013.28.3.374.

12. Sharma SK, Mohan A, Tamilarasu K. HIV-TB coinfection: epidemiology, diagnosis \& management. Indian J Med Res 2005;121(4):550-567.

13. Londhey VA. HIV and tuberculosis - A "cursed duo" in the HAART Era. [Last accessed on Feb 14, 2017]. Available from: http://www.japi.org/ october_2009/article_01.pdf.

14. Narain JP, Lo YR. Epidemiology of HIV-TB in Asia. Indian J Med Res 2004;120(4):277-289.

15. WHO. Global Tuberculosis Report 2015. Geneva, World Health Organization. (homepage on internet).c2015. (updated 31 Mar 2015, cited 30 Nov 2015). Available at www.who.int/tb/publications/ global_report/gtbr14_executive_summary.pdf (last Assessed on 25 Mar 2017).

16. Carvalho B, Monteiro A, Neto R, et al. Factors related to HIV/ tuberculosis co-infection in a Brazilian reference hospital. Braz J Infect Dis 2008;12(4):281-286. DOI: 10.1590/s1413-86702008000400005.

17. Rajasekaran S, Mahilmaran A, Annadurai S, et al. Manifestation of tuberculosis in patients with human immunodeficiency virus,
Chennai, India. Annals of Thoracic Medicine Journal 2006;2(2):58-60 DOI: 10.4103/1817-1737.32231.

18. Shetty N, Shemko M, Vaz M, et al. An Epidemiological evaluation of risk factors for tuberculosis in South India. Int J Tuber Lung Dis 2006;10(1):80-86.

19. Raizada N, Singh C, Khera A, et al. HIV Seroprevalence among tuberculosis patients in India, 2006-2007. PLoS ONE 2008;3(8):2970. DOI: 10.1371/journal.pone.0002970.

20. Annual Report 2014-15. National AIDS Control Organization, Department of AIDS Control. Ministry of Health \& Family Welfare, Government of India.

21. Badri M, Wilson D, Wood R. Effect of highly active antiretroviral therapy on incidence of tuberculosis in South Africa: a cohort study. Lancet 2002;359(9323):2059-2064. DOI: 10.1016/S01406736(02)08904-3.

22. Tran TM, Nguyen HT, Yatsuya $H$, et al. HIV prevalence and factors associated with HIV infection among male injection drug users under 30s: a cross sectional study in long an, Vietnam. BMC Public Health 2006;6(1):248. DOI: 10.1186/1471-2458-6-248.

23. Yadav SP, Dixit AK. A study of the potential interventional variables associated with delay in diagnosis/treatment of pulmonary tuberculosis cases in the Thar desert of Rajasthan. DMRC Annual Report; 2005-06. pp. 39-44.

24. Sonnenberg P, Glynn JR, Fielding $K$, et al. How soon after infection with HIV does the risk of tuberculosis start to increase? A retrospective cohort study in South African gold miners. J Infect Dis 2005;191(2):150-158. DOI: 10.1086/426827. 